\title{
Defoliation frequency and intensity effects on pasture for- age quality
}

IRAJ MOTAZEDIAN AND STEVEN H. SHARROW

\begin{abstract}
Both quantity and quality of pasture forage produced generally varies with frequency and intensity of plant defoliation. However, intensity and frequency of defoliation have rarely been evaluated simultaneously. The objective of this study was to quantify forage quality response to simultaneous changes in defoliation treatments over a range of values likely to occur in short-duration grazing systems. Effects of defoliation treatments on forage digestibility (DMD), crude protein content (CPC), crude protein yield, and digestible dry matter yield were evaluated on a perennial ryegrass (Lolium perenne, L.)-subclover (Trifolium subterraneum L.) hill land pasture growing on a Ultic Haploxeroll soil near Corvallis, Oregon. Treatments consisted of all possible combinations of 4 defoliation intervals (clipped every $7,21,35$, or 49 days) and 3 stubble heights (High-70, Medium-55, or Low-40 mm of stubble remaining after defoliation) applied during the 1980, 1981, and 1982 growing seasons. Digestible dry matter yield increased with increasing defoliation interval. With the exception of DMD in 1980 , both digestibility and CPC of the forage produced decreased linearly as the period between defoliation events increased. Crude protein content increased linearly as stubble height increased, while forage digestibility was comparatively insensitive to changes in stubble height. Forage quality was generally adequate on all treatments to meet the needs of most classes of livestock.
\end{abstract}

Key Words: crude protein yield, digestible dry matter yield, pasture management, short duration grazing, perennial ryegrass (Lolium perenne), subclover (Trifolium subterraneum)

Forage quality must be considered along with total dry matter yield in designing pasture management systems for livestock production. Low quality forage, even if abundant, may be associated with low forage intake and poor performance of livestock (Ellis 1978, Humphreys 1966). Ideal pasture management would maximize both the quantity and quality of forage available to livestock. This is not always possible, however, because infrequent or lowintensity defoliation which maximizes forage production (Brougham 1959, Ludlow and Charles-Edwards 1980, Wilman and Asiegbu 1982) may reduce crude protein and digestibility of the forage produced (Allinson et al. 1969, Chestnutt et al. 1977, Woodman and Stewart 1932). In practice, a balance must be sought between the quality and quantity of forage produced. Short duration grazing systems attempt to achieve this balance through control of frequency and intensity of defoliation events. A substantial body of information exists concerning the individual effects of frequency or intensity of defoliation on forage yield (Humphreys 1966, Smetham 1977). However, much less is known about effects on forage quality when these factors are applied concurrently over a range of values likely to be encountered in high-intensity grazing systems.

The purpose of this paper is to quantify the effects of different frequencies and intensities of defoliation on crude protein content,

\footnotetext{
Authors are research associate, Department of Resource Recreation, and professor, Department of Rangeland Resources, Oregon State Univ., Corvallis 97331.

This article was submitted as Technical Paper 8108. Oregon Agricultural Experiment Station, Corvallis.

Manuscript accepted 19 October 1989.
}

dry matter digestibility, crude protein yield, and digestible dry matter yield of forage obtained from perennial ryegrass-subclover pastures.

\section{Materials and Methods}

The study area was located on a south-facing hillside $1 \mathrm{~km}$ northwest of Corvallis, Oregon. Elevation is approximately $100 \mathrm{~m}$. The climate is maritime with mild, wet winters and warm, dry summers. Average annual precipitation is approximately 1,030 $\mathrm{mm}$; average monthly temperatures range from a low of $4^{\circ} \mathrm{C}$ in January to a high of $19^{\circ} \mathrm{C}$ in July and August; average frost-free period is 189 days (Redmond et al. 1984). Climatic data from a station approximately $16 \mathrm{~km}$ northeast of the study area (NOAA, $1980,1981,1982)$ indicated that soil and air temperatures were near average in 1980, 1981, and 1982. Precipitation during this period was above the 30-year average, being $1,050,1,170$, and $1,187 \mathrm{~mm}$ during 1980,1981 , and 1982, respectively. Vegetation consisted of an old, well-established perennial ryegrass (Lolium perenne L.)subclover (Trifolium subterraneum L.) stand containing approximately $55 \%$ ryegrass and $25 \%$ subclover at initiation of the experiment in 1980. Soil is a Hazelair silt loam (fine, mixed, mesic Ultic Haploxeroll; Knezevich 1975).

A $20 \times 40$-m exclosure was built in March 1980 to protect plots from sheep (Ovis aries) grazing. Thirty-six $4-\mathrm{m}^{2}$ permanently marked plots within the exclosure were assigned randomly within blocks to defoliation treatments. Treatments included 3 replications of all possible combinations of 4 defoliation intervals $(\mathrm{DI}=7$, 21,35 , or 49 days between consecutive defoliations), and 3 stubble heights $(\mathrm{SH}-$ High $=70 \mathrm{~mm}$, Medium $=55 \mathrm{~mm}$, or Low $=40 \mathrm{~mm}$ stubble remaining after defoliation). Plots received the same treatment each year of the study.

A rear-bagging rotary mower was used to defoliate plots. Contents of the mower bag from each plot was weighed and a grab sample obtained for oven-dry matter determination and chemical analysis. Grab samples were ground to pass a 1-mm sieve and stored in sealed plastic bags for chemical analysis. Treatments commenced each spring when pasture height reached $15 \mathrm{~cm}$. Following this criterion, treatments began 5 April, $24 \mathrm{March}$, and 7 April in 1980, 1981, and 1982, respectively. Treatments and collection continued throughout the spring to summer growing season. Work has terminated in July each year when the sward entered summer dormancy.

Plots were fertilized with $150 \mathrm{~kg} \mathrm{ha}^{-1}$ of superphosphate in September each year. In addition, $2.5 \mathrm{~kg} \mathrm{ha}^{-1}$ of sodium molybdate was applied March 1980 to correct a possible Mo deficiency.

Two-stage in vitro rumen fermentation (Tilley and Terry 1969) was used to determine forage digestibility. Rumen liquor was obtained from rumen-fistulated sheep fed ryegrass hay. Crude protein $(\mathrm{N} \times 6.25)$ was determined using a micro-Kjeldahl method (AOAC 1970). Yields of digestible forage and crude protein were calculated for each plot by multiplying digestibility and crude protein by the corresponding dry matter yield.

Data were analyzed as a split plot in time with DI and SH as main plots and years as subplots in a randomized complete block 


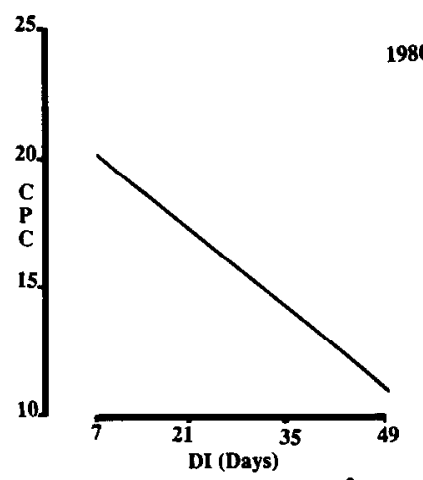

$\mathrm{CPC}(\%)=19.70 \cdot 0.181(\mathrm{DI}) \quad \mathrm{R}^{2}=0.85$

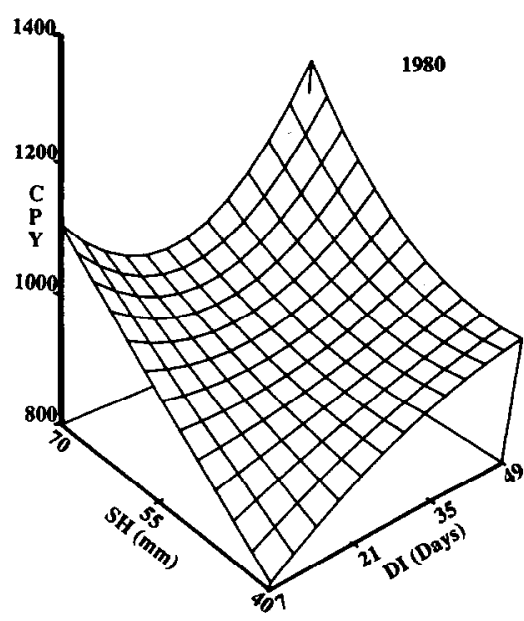

$\mathrm{CPY}(\mathrm{kg} / \mathrm{ha})=-174.0+66.6(\mathrm{DI})-0.447(\mathrm{DI})^{2}+23.7(\mathrm{SH})$ $-1.310(\mathrm{DIXSH})+0.0002\left(\mathrm{DIXSH}^{2}\right.$

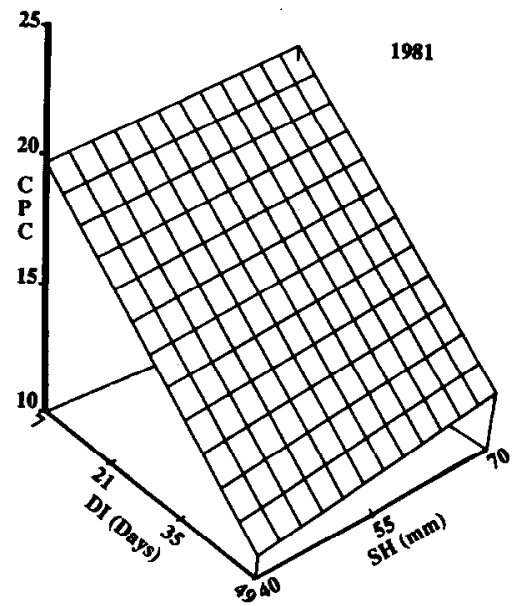

$\mathrm{CPC}(\%)=21.18 \cdot 0.21(\mathrm{DI})+0.05(\mathrm{SH}) \quad \mathrm{R}^{2}=0.98$

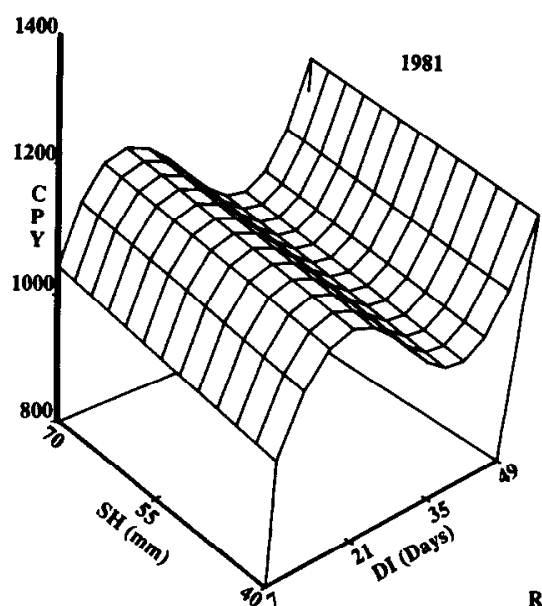

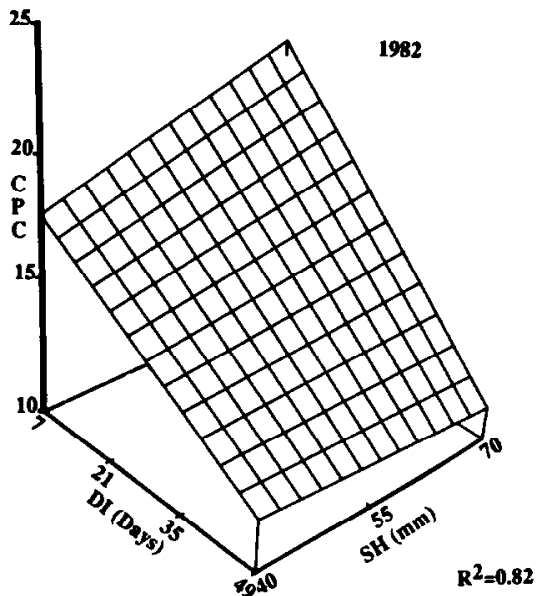

$\mathrm{CPC}(\%)=15.96-0.003(\mathrm{DI})+0.164(\mathrm{SH})-0.004(\mathrm{DIXSH})$

CPY $(\mathrm{kg} / \mathrm{hg})=602.0+76.4(\mathrm{DI})-3$.

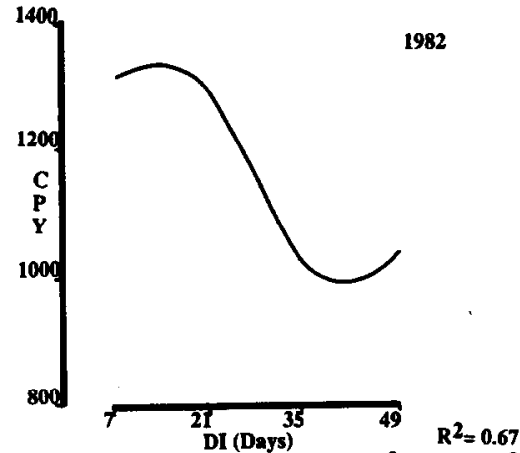

$\mathrm{CPY}(\mathrm{kg} / \mathrm{ha})=871.0+88.6(\mathrm{DI})-4.091(\mathrm{DI})^{2}+0.049(\mathrm{DI})^{3}$

Fig. 1. Effects of defoliation interval (DI) and stubble height (SH) on forage crude protein content (CPC) and crude protein yield (CPY) during 1980, 1981 , and 1982.

design with 3 replications (Steel and Torrie 1980). Because treatments $X$ year interactions were evident, data were further analyzed within year as a factorial arrangement of treatments in a randomized complete block design with 3 replications each year. Means, where appropriate, were separated by Student-Newman-Keul's test (Steel and Torrie 1980). Significant treatment effects were partitioned into orthogonal polynomial components, and response surfaces were fitted by least squares regression procedures (Neter and Wasserman 1974). Polynomials up to cubic terms for DI and up to quadratic terms for SH treatments, together with their interaction (DI $\times \mathrm{SH})$, were introduced as independent variables in a stepwise regression procedure. Models with the highest $R^{2}$ and lowest mean square error were selected as the "best" models. Following $t$ tests, only those regression coefficients which significantly differed from zero $(P<0.05)$ were retained in the models (Neter and Wasserman 1974).

\section{Results and Discussion}

Yearly average crude protein and dry matter digestibility of the forage produced each year increased $(P<0.01)$ by approximately $2.5 \%$ during the 3 years of the study (Table 1 ). Total crude protein yield also increased during the interval from 1980 to 1982 . Total digestible dry matter yield, however, decreased $(P<0.05)$ during this period. Changes in forage crude protein and dry matter digestibility over time may be explained by an observed shift in species composition of the sward from grass to clover dominance during
Table 1. Yearly average dry matter digestibility (DMD), crude protein content (CPC), digestible dry matter yield (DDM) and crude protein yield (CPY) of the forage produced in 1980, 1981 and 1982.

\begin{tabular}{lcccc}
\hline \hline & \multicolumn{4}{c}{ Year } \\
\cline { 2 - 5 } Source & 1980 & 1981 & 1982 & Sy \\
\hline DMD (\%) & $63 \mathrm{a}^{1}$ & $65 \mathrm{~b}$ & $68 \mathrm{c}$ & 2.5 \\
CPC (\%) & $15 \mathrm{a}$ & $18 \mathrm{~b}$ & $20 \mathrm{c}$ & 1.4 \\
DDM (kg/ha) & $4930.0 \mathrm{~b}$ & $4705.5 \mathrm{a}$ & $4623.7 \mathrm{a}$ & 64.68 \\
CPY $(\mathrm{kg} / \mathrm{ha})$ & $1100.2 \mathrm{a}$ & $1244.0 \mathrm{~b}$ & $1298.8 \mathrm{c}$ & 18.56 \\
\hline
\end{tabular}

'Means in a row followed by different letters differ $(P<0.05)$.

the course of the study. While $22 \%$ of sward canopy cover in 1980 was subclover, by 1982 it had increased to $55 \%$ of total sward canopy (Motazedian and Sharrow 1987). Clovers generally have higher dry matter digestibility and crude protein than do associated grasses at similar stages of maturity (Smetham 1977). Perennial ryegrass monocultures, however, may produce higher total dry matter yields than do perennial ryegrass-clover stands (Harris and Thomas 1973). The higher crude protein and dry matter digestibility of ryegrass-clover pastures may compensate for their lower total dry matter yields (Ulyatt 1970). These concepts are consistent with our observations that increased clover dominance of the sward was associated with higher crude protein yield but lower digestible dry matter yield. 

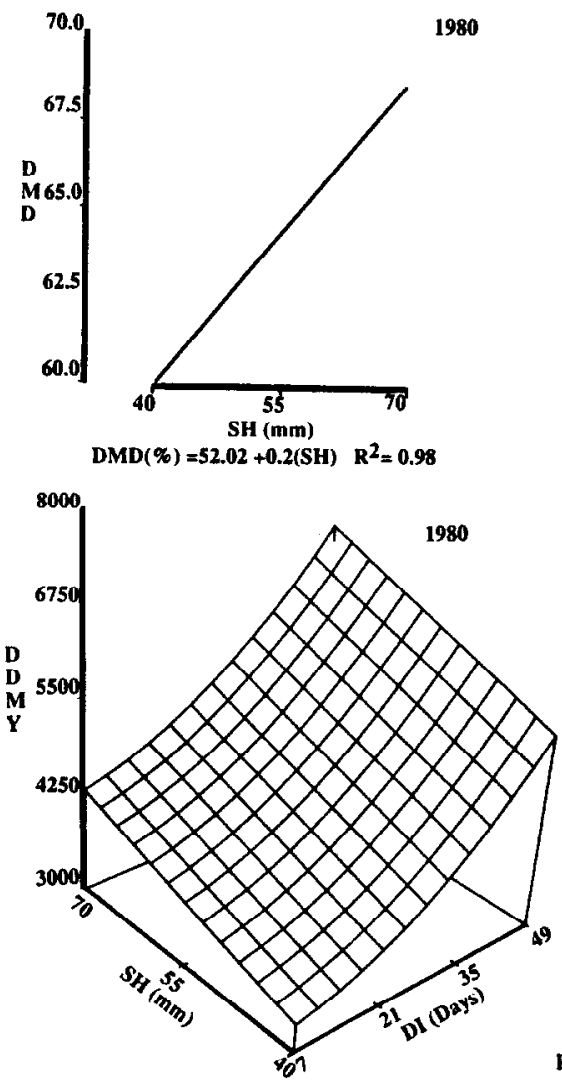

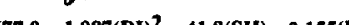

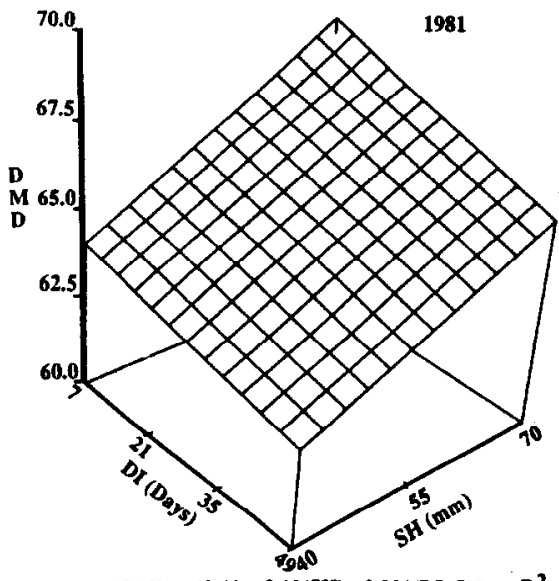

$\operatorname{DMD}(\%)=60.41+0.12(\mathrm{SH})-0.001(\mathrm{DIXSH}) \quad \mathrm{R}^{2}=0.65$
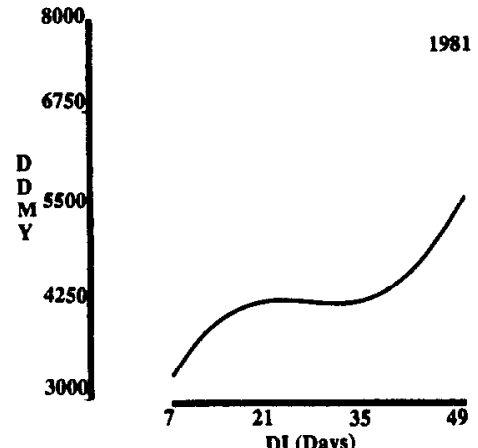

1981

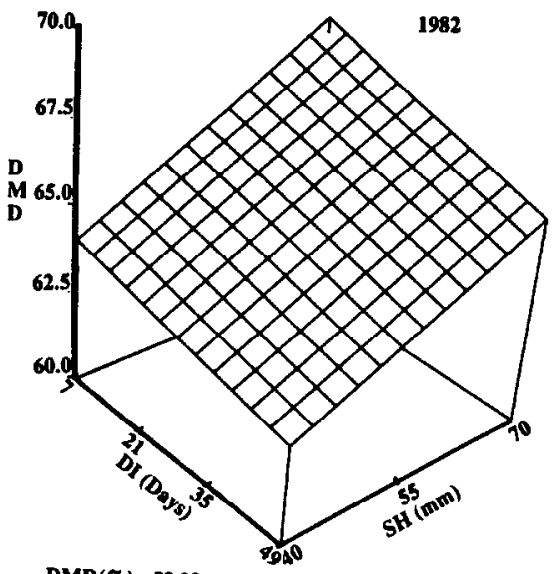

$\mathrm{DMD}(\%)=58.28+0.184(\mathrm{SH}) \cdot 0.001(\mathrm{DIXSH}) \quad \mathrm{R}^{2}=0.83$

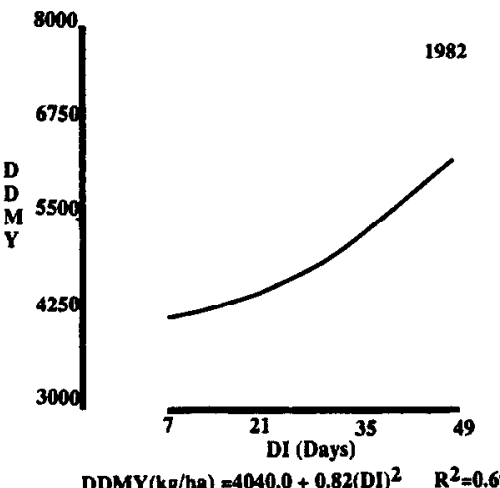

Fig. 2. Effects of defoliation interval (DI) and stubble height (SH) on digestible dry matter content (DMD) and digestible dry matter yield (DDMY) during 1980, 1981, and 1982.

Crude protein content $(C P C)$ declined $(P<0.01)$ as defoliation interval increased from 7 (DI-7) to 49 (DI-49) days between defoliation events (Fig. 1). Averaged over all 3 years, the observed decrease was approximately $0.2 \%$ less crude protein for each additional day between defoliations. A similar rate in the decline of crude protein with decreasing defoliation frequency was reported by Woodman and Stewart (1932). Response of dry matter digestibility to DI was less consistent than that of crude protein (Fig. 2). Digestibility decreased $(P<0.05)$ as DI increased in both 1981 and 1982. The degree of reduction in forage digestibility as DI increased was related to stubble height, with defoliation effects becoming more prominent as DI and SH increased. These findings are in general agreement with other reports (Binnie and Harrington 1972, Clark et al. 1974, Wilman et al. 1976) that both crude protein and digestibility of forage decline as defoliation interval increases. The observed numerical difference in dry matter digestibility resulting from defoliation every week compared to defoliation every 7 weeks is not large, being only about 1,3 , and $1 \%$ in 1980,1981 , and 1982 , respectively. This decline is less than the $8 \%$ lower digestibility reported for DI-42 compared to DI-14 treatments for a perennial ryegrass stand by Chestnutt et al. (1977), but similar to the $1 \%$ difference in digestible organic matter of DI-17 vs. DI-35 treatments noted by Woodman and Stewart (1932).

Stubble height was a significant component of 1981 and 1982 CPC response surfaces (Fig. 1); however, stubble height had little numerical impact on CPC values during any year of our study. Forage digestibility (Fig. 2) was apparently more sensitive to stubble height than was the crude protein content of forage. Averaged over all 3 years, observed forage digestibility decreased by approximately $0.16 \%$ per $1-\mathrm{mm}$ decrease in stubble height, while observed crude protein decreased by only $0.03 \%$ per $1 \mathrm{~mm}$ as defoliation height varied from 70 to $40 \mathrm{~mm}$. These results are consistent with observations that digestibility of perennial ryegrass (Taylor and Rudman 1966) and legumes (Mowat et al, 1965) declined as harvest height declined. Several authors, however, have reported no difference in either percent crude protein or digestibility of forage from plots harvested at different heights (Clark et al. 1974, Reid 1967). Binnie and Harrington (1972), while observing no difference in the digestibility of Italian ryegrass (Lolium multiflorum L.) harvested at 2.5 compared to $6.5 \mathrm{~cm}$ stubble heights, reported lower crude protein of forage at the lower height. Clearly more work relating the components of pasture yield and the age of plant organs harvested at different stubble heights need to be done before the effects of SH on forage quality will be fully understood.

Digestible dry matter yield increased $(P<0.05)$ rapidly with increasing DI during all 3 years of the study (Fig. 2). The response model relating digestible dry matter yield to stubble height and period of defoliation in 1980 consisted of a power curve for DI plus linear SH and DI $\times$ SH terms. Neither SH nor the DI $\times$ SH interaction was useful as a predictor of digestible dry matter yield in either 1981 or 1982. The difference in response between years is believed to reflect changes in species composition of the sward over time, as previously mentioned.

Similar to models for digestible dry matter yield, the response model relating DI and SH to crude protein yield in 1980 (Fig. 1) contained power curves for DI together with linear SH and DI $X$ SH components. The impact of $\mathrm{SH}$ on yields of both crude protein and digestible dry matter appeared to decrease over the 3 years of study; stubble height was not a component of either crude protein yield or digestible dry matter yield response surfaces in 1982. Our 
response models suggest that digestible dry matter yield and crude protein yield of perennial ryegrass-dominant swards are generally more responsive to changes in DI than in SH. These parameters, moreover, were less responsive to SH in clover-dominant (1981 and 1982) than in ryegrass-dominant (1980) stands. Presumably, differences in response to defoliation reflect differences between digestibility and crude protein content of grass and clover as they mature.

The general trend suggested by our response models is for digestible dry matter yield to increase as DI increases over the range of values evaluated. Increased digestible dry matter yield observed as DI increases from 7 to 49 days between defoliation was associated with lower crude protein content and, to a lesser degree, reduced digestibility of the dry matter harvested. In no case did crude protein content drop below $10 \%$ of the dry matter. In the cloverdominant swards of 1981 and 1982 , the lowest crude protein value recorded was $13 \%$. If one allows for a slightly higher forage quality in an animal's diet compared to the general value of the forage on offer (Bedell 1971), it is unlikely that dietary crude protein content will limit livestock performance under any of the defoliation regimes tested. It is more likely, as Smetham (1977) suggested, that livestock production on grass-clover pastures during spring and early summer will be limited by digestible energy intake rather than by crude protein content of the feed. He further speculated that increased digestible energy yield may be a primary cause of superior livestock performance under rotational grazing systems. This view is consistent with our observations that the short duration grazing practice of increasing defoliation interval produces pronounced increases in the yield of digestible dry matter. Increased yield of digestible dry matter under infrequent defoliation most likely results from dry matter yield increasing at a faster rate than its digestibility decreases with time since defoliation.

There is obviously a critical point at which forage digestibility is inadequate to achieve livestock production goals. The exact value of this critical point is somewhat arbitrary as it varies with the class and type of livestock, as well as with the level of livestock performance expected. Average daily gains of $290 \mathrm{~g} \mathrm{hd}^{-1} \mathrm{day}^{-1}$ may be achieved by lambs grazing perennial ryegrass-subclover pastures of $66 \%$ digestible dry matter and 9-10\% crude protein content (Thetford 1976). Using these values as a guide, a 35-day interval between grazing events appears to optimize the quality and quantity of forage produced from the grass-dominant pasture in 1980 . This defoliation interval is also near optimum for maintaining perennial ryegrass in the sward (Motazedian and Sharrow 1987). Clover-dominant pastures decline in quality more slowly than do grass-dominant pastures (Smetham 1977). Our data suggest that defoliation intervals of 49 days or even longer may be optimum for clover-dominant swards such as our 1982 sward.

\section{Literature Cited}

Allinson, D.W., M.B. Teser, and J.W. Thomas. 1969. Influence of cutting frequency, species, and nitrogen fertilization on forage nutritional value. Crop Sci. 9:504-508.

Association of Official Analytical Chemists (AOAC). 1970. Official methods of analysis (11th edition). Washington, D.C.

Bedell, T.E. 1971. Nutritive value of forage and diets of sheep and cattle from Oregon subclover-grass mixtures. J. Range Manage. 24:125-133.

Binnie, R.C., and F.J. Harrington. 1972. The effect of cutting height and cutting frequency on the productivity of an Italian rye-grass sward. $J$. Brit. Grass. Soc. 27:177-182.
Brougham, R.W. 1959. The effect of frequency and intensity of grazing on the productivity of a pasture of short-rotation ryegrass and red and white clover. New Zealand J. Agr. Res. 2:1232-1248.

Chestnutt, D.M.B., J.C. Murdoch, F.J. Harrington, and R.D. Binnie. 1977. The effect of cutting frequency and applied nitrogen on production and digestibility of perennial ryegrass. J. Brit. Grassl. Soc. 32:177-183.

Clark, J., C. Kat, and K. Santhirasegaram. 1974. The effects of changes in heights of cutting and growth on the digestible organic matter production and botanical composition of perennial pasture. J. Brit. Grass. Soc. 29:269-273.

Ellis, W.C. 1978. Determinants of grazed forage intake and digestibility. J. Dairy Sci. 61:1828-1840.

Harris, W., and V.J. Thomas. 1973. Competition among pasture plants. III. Effects of frequency and height of cutting on competition between white clover and two ryegrass cultivars. New Zealand. J. Agr. Res. 16:49-58.

Humphreys, L.R. 1966. Pasture defoliation practice: A review. J. Aust. Inst. of Agr. Sci. 32:93-105.

Knezevich, C.A.1975. Soil Survey of Benton County Area, Oregon. USDA Soil Cons. Serv., Washington D.C.

Ludlow, M.M., and D.A. Charles-Edwards. 1980. Analysis of regrowth of a tropical grass/legume sward subjected to different frequencies and intensities of defoliation. Aust. J. Agr. Res. 31:673-692.

Motazedian, I., and S.H. Sharrow. 1986. Defoliation effects on forage dry matter production of a perennial ryegrass-subclover pasture. Agron. J. 78:581-584.

Motazedian, I., and S.H. Sharrow. 1987. Persistence of a Lolium perenneTrifolium subterraneum pasture under differing defoliation treatments. J. Range Manage. 40:232-236.

Mowat, D.N., R.S. Fulkerson, W.E. Tossell, and J.E. Winch. 1965. The in vitro digestibility and protein content of leaf and stem portions of forages. Canadian J. Plant Sci. 45:321-331.

National Oceanic and Atmospheric Administration. 1978, 1980, 1981, and 1982. Oregon climatological data. Annual summary. Dep. Comm., Nat. Climatic Center, Asheville, N.C.

Neter, J., and W. Wasserman. 1974. Applied linear statistical models. Richard D. Irwin, Inc., Homewood, Ill.

Redmond, K.T., B.T. Kropp, and A.H. Murphy. 1984. Local climatological data for Corvallis, Oregon: 1983 Summary. Climatic Res. Inst. Rep. SCP-2, Corvallis, Ore.

Reid, D. 1967. Studies on the cutting management of grass-clover swards. $V$. The effect of changes in closeness of cutting at different times in the season on the yield and quality of herbage from a perennial ryegrasswhite clover sward. J. Agr. Sci. 68:249-254.

Smetham, M.L. 1977. Grazing management, p. 179-288. In: R.H.M. Langar (ed.). Pastures and pasture plants. A.H. and A.W. Reed Publishing, Sydney.

Steel, R.G.O., and J.H. Torrie. 1980. Principles and procedures of statistics. Second edition. McGraw-Hill Book Company, New York.

Tayler, J.C., and J.E. Rudman. 1966. Height and method of cutting or grazing in relation to herbage consumption and live-weight gain. Proc. 9th Int. Grassl. Congr. Sao Palo. p. 1639-1644.

Thetford, F.0. 1976. Responses of vegetation and sheep to three grazing pressures. Ph.D. Diss. Oregon State Univ., Corvallis.

Tilley, J.M.A., and R.A. Terry. 1969. The relationship between the soluble constituents of herbage and their dry-matter digestibility. J. Brit. Grass. Soc. 24:290-295.

Ulyatt, M.J. 1970. Evaluation of pasture quality under New Zealand conditions. Proc. N.Z. Grassl. Assoc. 32:61-68.

Wilman, D., and J.E. Asiegbu. 1982. The effects of clover variety, cutting interval and nitrogen application on herbage yields. Proportionsand heights in perennial ryegrass-white clover swards. Grass and Forage Sci. 37:1-13.

Wilman, D., A. Koocheki, and A.B. Lwoga. 1976. The effect of interval between harvests and nitrogen application on the proportion and yield of crop fractions and on the digestibility and digestible yield and nitrogen content and yield of two perennial ryegrass varieties in the second harvest year. J. Agr. Sci. 87:59-74.

Woodman, H.E., and J. Stewart. 1932. The mechanisms of cellulose digestion in the ruminant organisms. III. The action of cellulose-splitting bacteria on the fibre of certain typical feeding stuffs. J. Agr. Sci. 22:527-547. 